\title{
A sliding technique to load thin endothelial donor lamella onto Busin glide for Descemet-stripping automated endothelial keratoplasty
}

This article was published in the following Dove Press journal:

Clinical Ophthalmology

31 July 2012

Number of times this article has been viewed

\section{Akira Kobayashi \\ Hideaki Yokogawa \\ Kazuhisa Sugiyama}

Department of Ophthalmology, Kanazawa University Graduate School of Medical Science, Kanazawa, Japan
Correspondence: Akira Kobayashi Department of Ophthalmology, Kanazawa University Graduate School of Medical Science,

I3-I Takara-machi, Kanazawa-shi, Ishikawa-ken 920-864 I Japan

Tel +8I 762652403

Fax +8I 762229660

Email kobaya@kenroku.kanazawa-u.ac.jp
Abstract: We describe a modified technique for loading donor corneal endothelial lamella onto a Busin glide ${ }^{\circledR}$ without causing wrinkles, as part of the procedure of Descemet-stripping automated endothelial keratoplasty. Briefly, after punching out a composite of the donorendothelial lamella and a microkeratome-dissected cap, several drops of dispersive ophthalmic viscosurgical device are placed onto the endothelial surface. The Busin glide surface is then wetted with several drops of balanced salt solution. After the composite is transferred onto the Busin glide, hydrodissection of the potential space between the donor-endothelial lamella and the microkeratome-dissected cap is carefully performed to enable smooth detachment of these two lamellae. Whereas simply dragging the donor-endothelial lamella directly onto the glide can cause wrinkling or folding of the donor lamella, this technique enables smooth detachment of the composite without wrinkle or fold formation, and results in less endothelial cell damage.

Keywords: DSAEK, Busin glide, endothelial keratoplasty

Over several years, Descemet-stripping automated endothelial keratoplasty (DSAEK) has been successfully implicated in the treatment of endothelial dysfunctions. ${ }^{1-5}$ With this new procedure, meticulous care is taken during surgery to prevent the overmanipulation of very thin donor endothelial lamella that can result in the rapid reduction of endothelial cell count, or at worst, the development of primary graft failure.

In the original technique, the donor endothelial lamella was either folded in half, or overfolded into a 60/40 "taco" configuration, and grasped with forceps, after which it was inserted into the anterior chamber.$^{1-4}$ Recently, a new surgical insertion technique has been reported, in which the donor-endothelial lamella is pulled through scleral or corneal incisions. ${ }^{5-9}$ Busin has developed a new instrument (Busin donor glide ${ }^{\circledR}$, Cat \#19098; Moria, Antony, France) to hold the donor-endothelial lamella, and assist with insertion during the pull-through step. ${ }^{6,10,11}$ However, problems are sometimes encountered during the loading of the donor-endothelial lamella onto the Busin glide, when the donor lamella firmly attaches to the microkeratome-dissected residual-stromal cap; this attachment can cause folds to form in the donor lamella, and possible damage to endothelial cells (Figure 1A and B). To circumvent this problem, we developed a simple technique that enables smooth detachment of the donor-endothelial lamella from the microkeratome-dissected residual-stromal cap.

\section{Surgical technique}

On the day of surgery, all donor tissues are dissected in the operating room prior to the start of the first DSAEK surgery. Dissection is performed using a microkeratome 


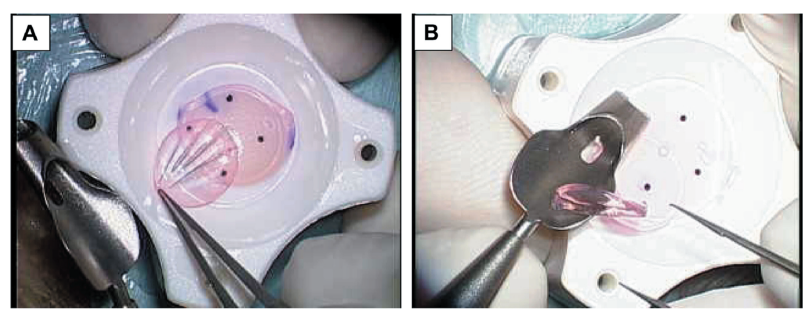

Figure I Problems that occur during donor-endothelial lamella loading onto a Busin glide. (A) Wrinkling of the donor lamella; (B) Folding of the donor lamella.

(ALTK Cbm; Moria Japan KK, Tokyo, Japan) equipped with a $300 \mu \mathrm{m}$ head. After microkeratome-dissection, the donor-endothelial lamella (with the repositioned, dissected cap) is transferred to a punching system, and cut with an $8.0 \mathrm{~mm}$ diameter punch (Barron Donor Cornea Punch; Katena Products Inc, Denville, NJ). The Busin glide surface is then wetted with several drops of balanced salt solution (Figure 2A). After the composite of donor-endothelial lamella and microkeratome-dissected cap is punched out, several drops of dispersive ophthalmic viscosurgical device are placed onto the endothelial surface (Figure 2B). Then, the composite is transferred onto the Busin glide (Figure 2C). Next, hydrodissection of the potential space between the

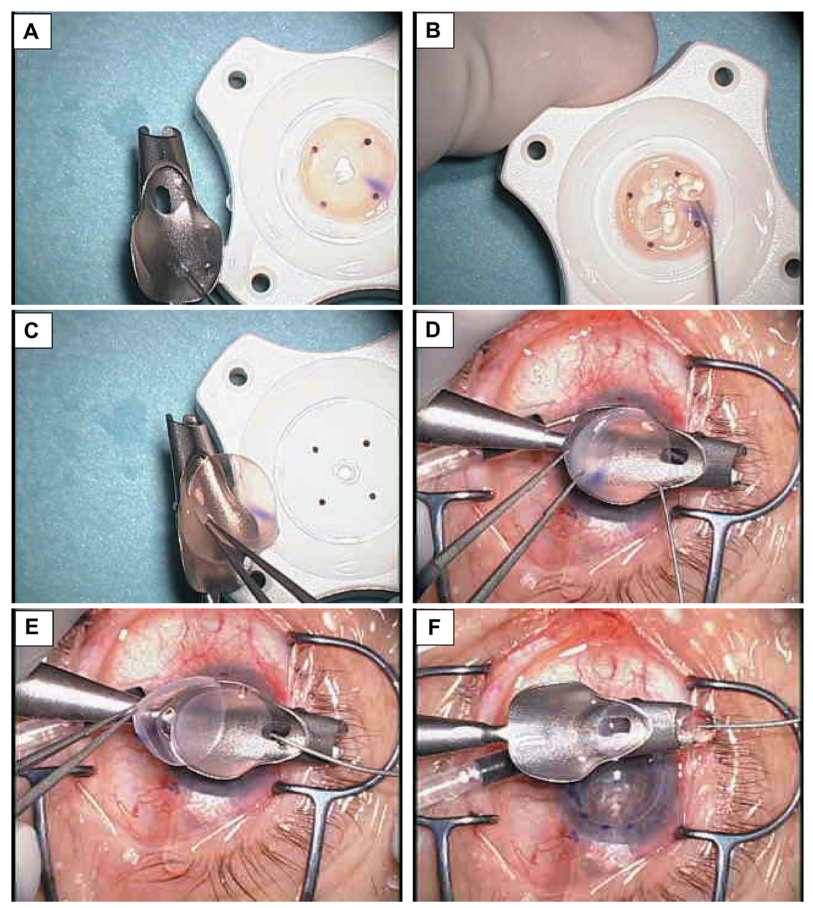

Figure 2 Technique for loading donor endothelial-lamella onto a Busin glide. (A) The Busin glide surface is wetted with several drop of balanced salt solution; (B) Drops of dispersive ophthalmic viscosurgical device are placed onto the endothelial surface; (C) The composite is transferred onto the Busin glide; (D) Hydrodissection of the potential space between donor-endothelial lamella and microkeratome-dissected cap; (E) The microkeratome-dissected stromal cap is removed without difficulty; (F) The donor lamella is pulled into the Busin glide opening. donor-endothelial lamella and the microkeratome-dissected cap is carefully performed, using ophthalmic irrigation solution (BSS Plus; Alcon, Fort Worth, TX) to enable smooth detachment of these two lamellae (Figure 2D). This technique enables smooth detachment of the composite, without causing the formation of any wrinkles or folds (Figure 2E). The donor lamella is then pulled into the Busin glide opening, using a 25-gauge anterior-capsular forceps (Cat \#MF8011; Inami Co, Ltd, Tokyo, Japan) (Figure 2F). Finally, the donor tissue is pulled into the anterior chamber from the Busin glide. ${ }^{7,8}$

\section{Discussion}

We reported herein a modified surgical technique, prewetting of the glide, and hydrodissection of the donor lamella aimed at optimizing the use of the Busin glide for DSAEK surgery. Hydrodissection of the donor lamella enables the smooth detachment of the composite of donor-endothelial lamella and microkeratome-dissected cap on the Busin glide without the formation of any wrinkles or folds.

This technique is quite useful when the DSAEK is performed using pre-cut tissue, as these tissues are usually distributed with the cap adhered to the dissected stromal bed. In ten out of ten consecutive cases, we saw that simply dragging donor-endothelial lamella directly onto the glide caused macroscopic wrinkling or folding of the donor lamella. It has been shown previously with in vitro vital dye staining 9 that folding of the donor endothelial lamella resulting from the forceps manipulation can cause endothelial cell damage. We too, have preliminary vital dye staining data (not shown here) that wrinkling or folding of the donor lamella as it is dragged onto the Busin glide causes endothelial cell damage.

To date, we have used this modified technique in more than 50 consecutive DSAEK cases, and no wrinkles or folds were caused during loading of the donor lamella onto the Busin glide. Furthermore, prewetting of the glide enabled quite smooth pull-through of the donor lamella in all cases. We strongly believe that this technique eliminates additional endothelial-cell loss caused by wrinkle formation, during donor manipulation. However, care should be exercised in using viscoelastic materials over the graft, especially on the stromal side, because of the increased risk of donor dislocation.

Currently, these modifications are our preferred endothelial keratoplasty technique during Busin glide use. Further studies are underway to quantify the actual benefit of this modified technique. 


\section{Disclosure}

The authors report no conflict of interest in this work.

\section{References}

1. Terry MA, Chen ES, Shamie N, Hoar KL, Friend DJ. Endothelial cell loss after Descemet's stripping endothelial keratoplasty in a large prospective series. Ophthalmology. 2008;115(3):488-496.

2. Price MO, Price FW Jr. Descemet's stripping with endothelial keratoplasty: comparative outcomes with microkeratome-dissected and manually dissected donor tissue. Ophthalmology. 2006;113(11):1936-1942.

3. Price FW Jr, Price MO. Descemet's stripping with endothelial keratoplasty in 200 eyes: Early challenges and techniques to enhance donor adherence. $J$ Cataract Refract Surg. 2006;32(3):411-418.

4. Gorovoy MS. Descemet-stripping automated endothelial keratoplasty. Cornea. 2006;25(8):886-889.

5. Kobayashi A, Mawatari Y, Yokogawa H, Sugiyama K. In vivo laser confocal microscopy after descemet stripping with automated endothelial keratoplasty. Am J Ophthalmol. 2008;145(6):977-985.
6. Aralikatti A, Dean S, Busin M, Shah S. Pull-through technique for graft insertion in DSAEK [author reply]. J Cataract Refract Surg. 2008;34(3): 341-342.

7. Kobayashi A, Yokogawa H, Sugiyama K. Descemet stripping with automated endothelial keratoplasty for bullous keratopathies secondary to argon laser iridotomy - preliminary results and usefulness of doubleglide donor insertion technique. Cornea. 2008;27 Suppl 1:S62-S69.

8. Kobayashi A, Yokogawa H, Sugiyama K. Non-Descemet stripping automated endothelial keratoplasty for endothelial dysfunction secondary to argon laser iridotomy. Am J Ophthalmol. 2008;146(4):543-549.

9. Mehta JS, Por YM, Beuerman RW, Tan DT. Glide insertion technique for donor cornea lenticule during Descemet's stripping automated endothelial keratoplasty. J Cataract Refract Surg. 2007;33(11): 1846-1850.

10. Busin M, Bhatt PR, Scorcia V. A modified technique for descemet membrane stripping automated endothelial keratoplasty to minimize endothelial cell loss. Arch Ophthalmol. 2008;126(8):1133-1137.

11. Jhanji V, Greenrod E, Sharma N, Vajpayee RB. Modifications in the surgical technique of Descemet stripping automated endothelial keratoplasty. Br J Ophthalmol. 2008;92(10):1311.
Clinical Ophthalmology

\section{Publish your work in this journal}

Clinical Ophthalmology is an international, peer-reviewed journal covering all subspecialties within ophthalmology. Key topics include: Optometry; Visual science; Pharmacology and drug therapy in eye diseases; Basic Sciences; Primary and Secondary eye care; Patien Safety and Quality of Care Improvements. This journal is indexed on

Submit your manuscript here: http://www.dovepress.com/clinical-ophthalmology-journal

\section{Dovepress}

PubMed Central and CAS, and is the official journal of The Society of Clinical Ophthalmology (SCO). The manuscript management system is completely online and includes a very quick and fair peer-review system, which is all easy to use. Visit http://www.dovepress.com/ testimonials.php to read real quotes from published authors. 